\title{
Teacher Self-Efficacy Perceptions and Metacognitive Learning Strategies of Pre-Service Mathematics Teachers
}

\section{Matematik Öğretmeni Adaylarının Özyeterlik Algıları ve Üstbiliş Öğrenme Stratejileri}

\author{
Nur SIRMACI**, Fatih TAŞ***
}

\begin{abstract}
This research aims to investigate whether there is a meaningful relationship between "Teacher Selfefficacy Perceptions" and "Metacognitive Learning Strategies" of pre-service Mathematics teachers and whether "Teacher Self-efficacy Perceptions" and "Metacognitive Learning Strategies" of pre-service Mathematics teachers differentiate depending on gender and grade levels. The study was carried out on a total of 191 students, 111 of which were females and 80 of which were male, studying at the Department of Mathematics Teaching at Kazım Karabekir Faculty of Education in Ataturk University. The findings were obtained by means of "Teacher Self Efficacy Perceptions Scale" developed by Tschannen-Moran and Woolfolk (2001) and adopted into Turkish by Çapa, Çakıroğlu and Sarıkaya (2005) and "Metacognitive Learning Strategies Scale" developed by Namlu (2004). According to the research findings, pre-service mathematics teachers' levels of teacher self-efficacy and their knowledge on the structure and processing of their own cognitive system are at "good" levels. It is understood that while pre-service mathematics teachers' perceptions of teacher self-efficacy do not vary by gender, they vary according to the levels of grade and the significant variance is between the 4th grade and others, in favour the 4th grade students. When the sub-dimensions of the metacognitive learning strategies scale was analyzed, a significant variance was found in "organization strategies" and "managing strategies" sub-dimensions by gender in favour of female participants. And also pre-service mathematics teachers' scores of metacognitive learning strategies by grade was found to be significant. In the study, a significant wasn't found between pre-service mathematics teachers' perceptions of teacher self-efficacy and their metacognitive learning strategies.
\end{abstract}

Keywords: Teacher efficacy perceptions, metacognitive learning strategies, pre-service mathematics teachers

ÖZ: Bu araştırmanın amacı matematik öğretmeni adaylarının özyeterlik algısı ile üstbiliş öğrenme stratejileri arasında anlamlı bir ilişki olup olmadığı ve sınıf, cinsiyete göre farklılaşıp farklılaşmadığını araştırmaktır. Araştırmanın çalışma grubunu 111'i kız, 80’i erkek olan 191 Atatürk Üniversitesi Kazım Karabekir Eğitim Fakültesi Matematik Öğretmenliği Bölümü öğrencileri oluşturmuștur. Veri toplama aracı olarak Çapa, Çakıroğlu ve Sarıkaya (2005) tarafından Türkçe'ye uyarlanan Öğretmen Özyeterlik Alg1 Ölçeği ve Namlu (2004) tarafindan geliştirilen Üstbiliş Öğrenme Stratejileri Ölçeği kullanılmıştır. Araştırma sonuçlarına göre, öğretmen adaylarının öğretmen özyeterlik algısı düzeyleri ve kendi biliş sistemi yapısı, çalışması hakkındaki bilgisi “iyi” düzeydedir. Öğretmen adaylarının öğretmen yeterlik algısı düzeyleri cinsiyetlerine göre değişmezken, sınıf düzeylerine göre farklılık gösterdiği ve anlamlı farklılığın dördüncü sınıf ile diğer sınıflar arasında, dördüncü sınıfların lehine olduğu anlaşılmaktadır. Bilişötesi öğrenme stratejileri ölçeği alt boyutları incelendiğinde, cinsiyet değişkenine göre "örgütleme stratejileri" ve "denetleme stratejileri" alt boyutlarında kız adayların lehine anlamlı farklılık bulunmuştur. Ve aynı zamanda matematik öğretmeni adaylarının üstbiliş öğrenme stratejilerinin sınıf düzeyine göre de farklılaştığı bulunmuştur. Araştırmada, öğretmen adaylarının özyeterlik algıları ile bilişötesi öğrenme stratejileri arasındaki ilişki anlamsız bulunmuştur.

Anahtar sözcükler: Öğretmen özyeterlik algısı, üstbiliş öğrenme stratejileri, matematik öğretmeni adayları

\section{INTRODUCTION}

\footnotetext{
* This study was presented as an oral presentation at the 5th WCES February, 2013 in Italy.

*** Assist. Prof., Atatürk University, nsirmaci@yahoo.com

**** Res. Assist., Bartın University, fatihhtass@ gmail.com
} 
Metacognition is defined as the individual's awareness of the learning process and the regulation of the process such as control and monitoring in this process (Brown, 1987; Flavell, 1987; and, Nelson and Narens, 1996). According to Hacker (1998), metacognition and cognition differ from each other in their functions. The function of cognition is to suggest cognitive attempts for solving problems and reaching a good outcome. On the other hand, the function of metacognition is to regulate the cognitive process of individuals in problem solving and to guide any task overtaken. This distinction can be exemplified as individuals' becoming aware of his not understanding, removing the factors around which inhibit their understanding, and conscious use of their memory in order to foster their understanding.

Metacognitive skills are used for monitoring and regulating cognitive processes. The processes such as problem solving, understanding, reasoning, and memory can be given as examples to metacognition. In various studies, the relationship between metacognition and intelligence was investigated and the importance of metacognitive strategies in the use intellectual skills was emphasized (Hertzog \& Robinson, 2005; Sternberg, 2005; Sternberg \& Ben-Zeev, 2001). These strategies are the successive processes which the individuals use in cognitive activities. While these strategies help to regulate and control cognitive practices, they, at the same time, involve planning and monitoring the cognitive practices (Özsoy, 2007).

Metacognition refers to the processes of individuals' thinking on their own thinking and it plays a great role in self-regulation (Zimmerman \& Schunk; 2003). If a student, before learning a new subject, realizes that the background student already has will affect what student will learn and asks themself what student knows and plans what student needs to do in order to bridge the gaps, it means student uses metacognitive strategies. To Roberts and Erdos, once metacognitive strategies are developed, students can use them for their personal development and academic performances (as cited in Namlu, 2004). Metacognitive knowledge and metacognitive strategies increase the effectiveness of the learning process by fostering individuals' awareness. Use of metacognitive skills in a course like mathematics, which requires high level of analytical thinking skills, is quite important.

According to Bednarik and Keinonen (2011), individuals' awareness of the learning process affects their learning performance. According to some studies, individuals who have prediction skill have higher learning levels. These individuals have a variety of metacognitive skills. When needed, they use the most effective strategy. The students learning in a strategical way and use learning strategies effectively are those who have metacognition learning styles and processes. They use strategies such as summarizing in order to reach their learning goals. It is necessary to discipline students for such self-learning activities (Eggen \& Kauchak, 2001:338,339; Davis \& Davis, 2000:85).

According to Bandura, self-efficacy belief is based on the belief about our abilities and it is necessary to regulate any behavior in order to reach certain goals and perform this behavior (Schmitz \& Schwarzer, 2000). To Bandura (1986), perception of self-efficacy is the belief of people related to organizing and carrying out the required activities to realize a certain performance. According to Kurt (2012) and Social Cognitive Theory, the basic motive underlying the behaviors of individuals is their self-efficacy beliefs. Leithwood (2007) indicated that selfefficacy is not a real ability or capacity of the individual: he describes it as the belief of the individual pertaining to his ability or capacity. A person may find his performance for a certain activity adequate. However, his performance may be inadequate in reality. For instance, a perfectionist person who always pursues the better may not find his performance adequate. Nevertheless, his performance may actually be adequate enough. For this reason, it can be said self-efficacy is perceptual and it may not be completely consistent with the level of an individual's real performance. It is reported that when people perceive their self-efficacy level a 
little bit higher than it actually is, this may have the greatest positive effect on performance (Goddard, Hoy \& Woolfolk, 2004).

Tschannen-Moran and Woolfolk-Hoy (2001) define teachers' self-efficacy beliefs as "a teacher's belief related to capacity or ability to construct the desired learning outcomes". Guskey and Passaro (1994) define the same concept as "teachers' self-confidence in offering their students an effective education-instruction". Self-efficacy belief is used in the area of education to explain individual differences in teachers' performances and it makes great contributions to understanding and developing teacher behaviors (Riggs \& Enochs, 1990). The teachers with strong self-efficacy beliefs have greater eagerness and passion for teaching and this creates an experience of expertise for their students (B1kmaz, 2004). The teachers with low level of selfefficacy are more open to, in particular, professional troubles. It is asserted that the teachers with weak self-efficacy are exposed to sources of chronic professional stress including physical and emotional exhaustion, memory loss at work, and feeling of uselessness pertaining to personal success (Gibson \& Dembo, 1984). According to Kurt (2012), teachers' self-efficacy beliefs about fulfilling their responsibilities have relationship with students' academic achievement, motivation, classroom management skills, preferences of methods, the time allotted to teaching, and the effort given for the students to be successful.

Self-efficacy beliefs belonging to affective sides of students, teachers and pre-service teachers are encountered as the important concepts to be dealt with in education (Aşkar \& Umay, 2001). It is important to determine pre-service mathematics teachers' professional proficiency and self-efficacy in order for them to achieve a successful instruction while they are doing their jobs in the future. Because research shows that teachers' self-efficacy beliefs related to teaching have effects on their teaching performances (Brownell \& Pajares, 1999). The studies on teacher behaviors in this sense emphasize the expectations and beliefs about the teaching proficiencies which affect learners' motivation and achievement (Eshach, 2003).

\subsection{Aim of Study}

This study was conducted to find out whether there is a significant relationship between pre-service mathematics teachers' perceptions of teacher self-efficacy and their metacognitive learning strategies and whether these perceptions of teacher self-efficacy and metacognitive learning strategies vary according to their gender and grades. For these purposes, answers were sought for the following questions:

1. What is the level of pre-service mathematics teachers' perceptions of teacher selfefficacy?

1.1. Is there a significant difference between their perceptions of teacher self-efficacy according to their gender?

1.2. Is there a significant difference between their perceptions of teacher self-efficacy according to their grade?

2. What is the level of pre-service mathematics teachers' metacognitive learning strategies?

2.1. Is there a significant difference between their metacognitive learning strategies according to their gender?

2.2. Is there a significant difference between their metacognitive learning strategies according to their grade?

3. Is there a significant correlation between pre-service mathematics teachers' perceptions of teacher self-efficacy and their metacognitive learning strategies? 


\section{METHOD}

A survey research was used in this study. Surveys are the research approaches aiming to describe a certain case or a phenomenon as it is. Here, the case, event, individual, or object which is under investigation is tried to be defined in its own context and as it is (Karasar, 2005).

\subsection{Study Group}

The participants of the study consist of 191 pre-service mathematics teachers who were the students at Atatürk University Kazım Karabekir Faculty of Education Primary Mathematics Teaching Department in 2011-2012 academic year. The distribution of the research participants according to their gender and grade is given in Table 1.

Table 1: Distribution of the pre-service teachers participated in the research according to their gender and grade

\begin{tabular}{lcccccccccc}
\hline & \multicolumn{2}{c}{ Grade 1 } & \multicolumn{2}{c}{ Grade 2 } & \multicolumn{2}{c}{ Grade 3 } & \multicolumn{2}{c}{ Grade 4 } & \multicolumn{2}{c}{ Total } \\
\hline & $\mathbf{N}$ & $\mathbf{\%}$ & $\mathbf{N}$ & $\boldsymbol{\%}$ & $\mathbf{N}$ & $\boldsymbol{\%}$ & $\mathbf{N}$ & $\mathbf{\%}$ & $\mathbf{N}$ & $\boldsymbol{\%}$ \\
\hline Female & 28 & 77.8 & 30 & 53.6 & 29 & 56.9 & 24 & 50 & 111 & 58.1 \\
Male & 8 & 22.2 & 26 & 46.4 & 22 & 43.1 & 24 & 50 & 80 & 41.9 \\
\hline Total & 36 & 100 & 56 & 100 & 51 & 100 & 48 & 100 & 191 & 100 \\
\hline
\end{tabular}

As seen in Table 1, 191 pre-service teachers, 36 from 1st Grade, 56 from 2nd Grade, 51 from 3rd Grade, and 48 from 4th Grade, participated in the study. The participants consist of 111 $(58.1 \%)$ female and $80(41.9 \%)$ male pre-service teachers.

\subsection{Data Collection Instruments}

The Teacher Self-Efficacy Scale developed by Tschannen-Moran and Woolfolk (2001) was adapted to Turkish by Çapa, Çakıroğlu and Sarıkaya (2005). The scale which consists of three sub-dimensions such as "efficacy for student engagement", "efficacy for instructional strategies" and "efficacy for classroom management" and 24 items is a nine-point Likert scale. The possible lowest score from the scale is 24 and the highest is 216 . The Cronbach alpha coefficient for the whole scale was found to be .93 and the Cronbach alpha coefficients for the sub-dimensions were respectively as follows: .82 for "efficacy for student engagement"; .86 "efficacy for instructional strategies"; and .84 "efficacy for classroom management". In the study, the Cronbach alpha coefficients were found as .846 for "efficacy for student engagement"; .874 for "efficacy for instructional strategies"; .881 for "efficacy for classroom management", and .951 for the whole scale.

The Metacognitive Learning Strategies Scale developed by Namlu (2004) has a four-point Likert scale and 21 items. The options on the scale are Never (1), Sometimes (2), Often (3), and Always (4). The scale has four dimensions such as planning strategies, organizing strategies, managing strategies, and evaluation strategies. The Cronbach alpha coefficient for the whole scale was found to be .82 and the Cronbach alpha coefficients for the sub-dimensions were respectively as: .69 for planning strategies; .74 for organizing strategies, .67 for managing strategies, and .48 for evaluation strategies. In the study, the Cronbach alpha coefficients were found .743 for the whole scale, .524 for planning strategies; .793 for organizing strategies, .697 for managing strategies, and .532 for evaluation strategies. 


\subsection{Data Analysis}

In data analysis, frequencies, percentages, means and standard deviations were calculated; and some techniques of data analysis such as Independent Samples T Test, One-way ANOVA, Levene's Test and Pearson Product-Moment Correlation Coefficient were used.

\section{FINDINGS}

\subsection{Findings Related to Pre-service Mathematics Teachers' Perceptions of Teacher Self- Efficacy}

The Teacher Self-Efficacy Scale was given to pre-service mathematics teachers and the findings on the responses are presented in Table 2.

Table 2. Descriptives for the scores of pre-service mathematics teachers' perceptions of teacher selfefficacy

\begin{tabular}{lccc}
\hline Self-Efficacy Perceptions & N & M & SD \\
\hline Efficacy for student engagement & 191 & 38.07 & 7.199 \\
\hline Efficacy for instructional strategies & 191 & 52.78 & 9.100 \\
\hline Efficacy for classroom management & 191 & 52.66 & 9.467 \\
\hline Total & 191 & 157.15 & 26.141 \\
\hline
\end{tabular}

As illustrated in Table 2, the mean of pre-service mathematics teachers' perceptions of teacher self-efficacy scores was found as 157.15 As regards the means of their scores from the sub-dimensions of the Teacher Self-Efficacy Scale, they were respectively, 38.07, 52.78, and 52.66 for efficacy for student engagement, efficacy for instructional strategies, and efficacy for classroom management.

In order to identify whether pre-service mathematics teachers' perceptions of teacher selfefficacy scores vary according to their gender, a Levene's test was used. The distribution was determined to be homogeneous ( $p>.05$ ). For this reason, with $t$ test, it was tried to find out whether this difference between the scores were significant or not; the findings are displayed in Table 3 .

Table 3. $T$ table showing the variance between pre-service mathematics teachers' perceptions of teacher self-efficacy scores

\begin{tabular}{llccccc}
\hline Self-Efficacy Perception & Gender & $\mathbf{N}$ & $\mathbf{M}$ & SD & t & P \\
\hline \multirow{2}{*}{$\begin{array}{l}\text { Efficacy for student } \\
\text { engagement }\end{array}$} & Female & 111 & 38.06 & 7.283 & -.011 & .991 \\
\cline { 2 - 6 } $\begin{array}{l}\text { Efficacy for instructional } \\
\text { strategies }\end{array}$ & Male & 80 & 38.08 & 7.128 & & \\
\hline \multirow{2}{*}{$\begin{array}{l}\text { Efficacy for classroom } \\
\text { management }\end{array}$} & Female & 111 & 52.53 & 9.182 & -.444 & .658 \\
\cline { 2 - 6 } Total & Male & 80 & 53.12 & 9.032 & & \\
\cline { 2 - 6 } & Female & 111 & 52.14 & 9.353 & -.886 & .377 \\
\hline
\end{tabular}

$\overline{p>.05}$

As can be seen in Table 3, self-efficacy perceptions scores of female and male pre-service mathematics teachers were found to be close to each other: they were respectively 156.32 and 158.30. According to the results of the $t$ test conducted in order to find out whether the difference between the means was significant or not, the difference between the self-efficacy perceptions scores of female and male pre-service mathematics teachers is not significant. Namely, it can also 
be stated that self-efficacy perceptions scores of pre-service mathematics teachers do not vary according to their gender.

Descriptives related to the distribution of means of pre-service mathematics teachers' perceptions of teacher self-efficacy by their grades are given in Table 4.

Table 4. Distribution of means of pre-service mathematics teachers' perceptions of teacher self efficacy by their grades

\begin{tabular}{|c|c|c|c|c|c|c|c|c|c|c|c|c|}
\hline \multirow[b]{2}{*}{$\begin{array}{l}\text { Self-Efficacy } \\
\text { Perception }\end{array}$} & \multicolumn{3}{|c|}{ Grade 1} & \multicolumn{3}{|c|}{ Grade 2} & \multicolumn{3}{|c|}{ Grade 3} & \multicolumn{3}{|c|}{ Grade 4} \\
\hline & $\mathbf{N}$ & M & SD & $\mathbf{N}$ & $\mathbf{M}$ & SD & $\mathbf{N}$ & M & SD & $\mathbf{N}$ & M & SD \\
\hline $\begin{array}{l}\text { Efficacy for } \\
\text { student } \\
\text { engagement }\end{array}$ & \multirow{4}{*}{36} & 36.78 & 8.322 & \multirow{4}{*}{56} & 38.89 & 5.929 & \multirow{4}{*}{51} & 35.45 & 7.092 & \multirow{4}{*}{48} & 40.85 & 6.773 \\
\hline $\begin{array}{l}\text { Efficacy for } \\
\text { instructional } \\
\text { strategies }\end{array}$ & & 50.33 & 8.455 & & 55.43 & 7.797 & & 48.04 & 9.531 & & 56.56 & 7.863 \\
\hline $\begin{array}{l}\text { Efficacy for } \\
\text { classroom } \\
\text { management }\end{array}$ & & 49.53 & 9.714 & & 54.18 & 9.017 & & 49.22 & 9.815 & & 56.90 & 7.274 \\
\hline Total & & 149.9 & 26.53 & & 162.9 & 22.27 & & 145.0 & 27.04 & & 168.6 & 22.46 \\
\hline
\end{tabular}

As shown in Table 4, the highest teacher self-efficacy perception was found to belong to 4 th grade students and the lowest to 3rd grade students. When the results pertaining to the subdimensions of the scale were analyzed, it was realized that the 4th grade students had higher means than the other groups did. In order to identify whether this variance was significant or not, first a Levene's test was used: the distribution was determined to be homogeneous ( $p>.05)$. Then an analysis of variance was made: the results are given in Table 5.

Table 5. Table illustrating the variance between pre-service mathematics teachers' perceptions of teacher self-efficacy scores by grade

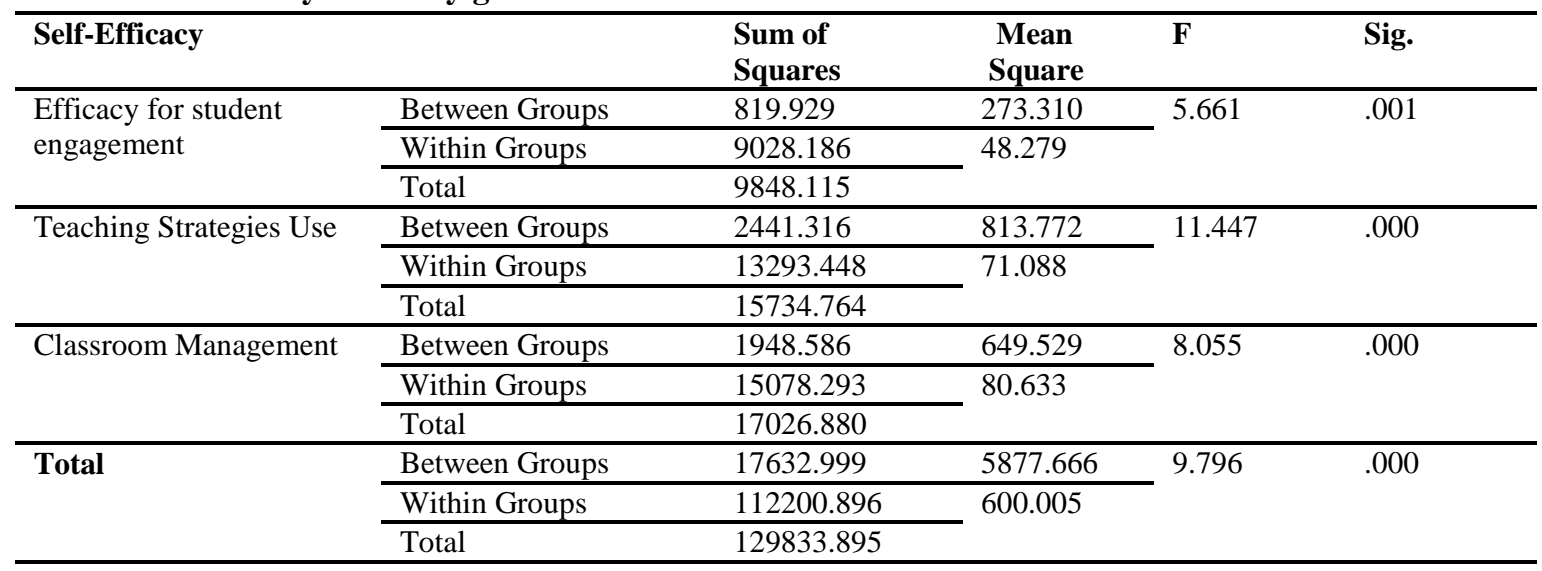

As illustrated in Table 5, the $\mathrm{F}$ values of the variance analysis of pre-service mathematics teachers' perceptions of teacher self-efficacy scores by grade were found to be significant $(\mathrm{p}=.05)$ at both the whole scale level and at the sub-dimensions level. A Sheffe test was used to explore between which groups the difference was and it was discovered that it was between the Grade 4 and other grades. 


\subsection{Findings Related to Pre-Service Mathematics Teachers' Scores of Metacognitive Learning Strategies}

Metacognitive Learning Strategies Scale was conducted with the participants: the findings are introduced in Table 6.

Table 6. Statistics for pre-service mathematics teachers' scores of metacognitive learning strategies

\begin{tabular}{lccc}
\hline Metacognitive Learning Strategies & N & M & SD \\
\hline Planning Strategies & 191 & 14.90 & 2.167 \\
\hline Organizing Strategies & 191 & 16.70 & 3.856 \\
\hline Managing Strategies & 191 & 14.82 & 2.672 \\
\hline Evaluation Strategies & 191 & 10.04 & 2.343 \\
\hline Total & 191 & 56.45 & 7.531 \\
\hline
\end{tabular}

According to Table 6, the mean of the scores of the pre-service mathematics teachers from the Metacognitive Learning Strategies Scale was found as 56.45. In order to understand whether the means of metacognitive learning strategies scores vary according to gender, first, a Levene's test was implemented and it was seen that the distribution was homogeneous; and then an independent samples $t$ test was used to reveal whether the variances between the means were significant or not. The findings are displayed in Table 7.

Table 7. T Table illustrating the variance between pre-service mathematics teachers' metacognitive Learning Strategies Scores

\begin{tabular}{|c|c|c|c|c|c|c|}
\hline Metacognitive Learning Strategies & Gender & $\mathbf{N}$ & $\bar{X}$ & $\mathbf{S S}$ & $\mathbf{t}$ & p \\
\hline \multirow[t]{2}{*}{ Planning Strategies } & Female & 111 & 14.97 & 1.988 & \multirow{2}{*}{.583} & \multirow{2}{*}{.561} \\
\hline & Male & 80 & 14.79 & 2.401 & & \\
\hline \multirow[t]{2}{*}{ Organizing Strategies } & Female & 111 & 17.34 & 3.743 & \multirow{2}{*}{$2.775^{*}$} & \multirow{2}{*}{.006} \\
\hline & Male & 80 & 15.80 & 3.853 & & \\
\hline \multirow[t]{2}{*}{ Managing Strategies } & Female & 111 & 15.22 & 2.546 & \multirow{2}{*}{$2.466 *$} & \multirow{2}{*}{.015} \\
\hline & Male & 80 & 14.26 & 2.759 & & \\
\hline \multirow[t]{2}{*}{ Evaluation Strategies } & Female & 111 & 10.05 & 2.270 & \multirow{2}{*}{.058} & \multirow{2}{*}{.954} \\
\hline & Male & 80 & 10.02 & 2.455 & & \\
\hline \multirow[t]{2}{*}{ Whole Scale } & Female & 111 & 57.58 & 7.027 & \multirow{2}{*}{$2.479 *$} & \multirow{2}{*}{.014} \\
\hline & Male & 80 & 54.88 & 7.959 & & \\
\hline
\end{tabular}

$* \mathrm{p}<.05$

While all the $\mathrm{t}$ values for the variances between the means of organization strategies, managing strategies, and the whole scale of female and male participants are significant at the level of $p<.05$, the variances between the means of planning strategies and evaluation strategies of them were not. In table 7 , it is seen that the means of female participants for organization strategies, managing strategies, and the whole scale are higher than the scores the males. These findings show a significant difference in favor of females in organization strategies, managing strategies, and the whole scale scores.

The distribution of pre-service mathematics teachers' metacognitive learning strategies scores by their grades is given in Table 8 . As seen in Table 8 , pre-service mathematics teachers' metacognitive learning strategies scores are close to each other. For testing the homogeneity of the data, the Levene's test was used and it was seen that the distribution was homogeneous ( $p>$ $.05)$; a One-Way Variance Analysis was conducted. The results of this analysis are given in Table 9. 
Table 8. Distribution of pre-service mathematics teachers' metacognitive learning strategies scores by their grades

\begin{tabular}{|c|c|c|c|c|c|c|c|c|c|c|c|c|}
\hline $\begin{array}{l}\text { Metacognitive } \\
\text { Learning } \\
\text { Strategies } \\
\end{array}$ & $\mathbf{N}$ & $\mathbf{M}$ & SD & $\mathbf{N}$ & $\mathbf{M}$ & SD & $\mathbf{N}$ & $\mathbf{M}$ & SD & $\mathbf{N}$ & $\mathbf{M}$ & SD \\
\hline $\begin{array}{l}\text { Planning } \\
\text { Strategies }\end{array}$ & \multirow{5}{*}{36} & 14.97 & 1.993 & \multirow{5}{*}{56} & 14.43 & 2.061 & \multirow{5}{*}{51} & 14.92 & 2.331 & \multirow{5}{*}{48} & 15.35 & 2.188 \\
\hline $\begin{array}{l}\text { Organizing } \\
\text { Strategies } \\
\end{array}$ & & 17.00 & 3.312 & & 16.30 & 4.191 & & 16.04 & 3.888 & & 17.62 & 3.699 \\
\hline $\begin{array}{l}\text { Managing } \\
\text { Strategies }\end{array}$ & & 14.64 & 2.428 & & 14.55 & 2.917 & & 14.14 & 2.408 & & 15.98 & 2.522 \\
\hline $\begin{array}{l}\text { Evaluation } \\
\text { Strategies } \\
\end{array}$ & & 10.97 & 2.751 & & 9.34 & 2.234 & & 9.69 & 2.168 & & 10.52 & 2.021 \\
\hline Total & & 57.58 & 6.600 & & 54.62 & 7.808 & & 54.78 & 7.363 & & 59.48 & 7.104 \\
\hline
\end{tabular}

As seen in Table 9, F value obtained from analyzing the variance between pre-service mathematics teachers' scores of metacognitive learning strategies by grade was found to be significant at the level of $\mathrm{p}<.05$ for the whole scale, "managing strategies", and "evaluation strategies". In order to find out between which groups the variance was, a Sheffe's test was used and it was found that the difference was between the 4th grade and 2nd-and-3rd grade students.

Table 9. F table illustrating the variance between pre-service mathematics teachers' metacognitive learning strategies scores by grade

\begin{tabular}{|c|c|c|c|c|c|}
\hline $\begin{array}{l}\text { Metacognitive Learning } \\
\text { Strategies }\end{array}$ & & $\begin{array}{l}\text { Sum of } \\
\text { Squares }\end{array}$ & $\begin{array}{c}\text { Mean } \\
\text { Square }\end{array}$ & $\mathbf{F}$ & Sig. \\
\hline \multirow[t]{3}{*}{ Planning Strategies } & Between Groups & 22.554 & 7.518 & 1.617 & .187 \\
\hline & Within Groups & 869.352 & 4.649 & & \\
\hline & Total & 891.906 & & & \\
\hline \multirow[t]{3}{*}{ Organizing Strategies } & Between Groups & 75.377 & 25.126 & 1.709 & .167 \\
\hline & Within Groups & 2749.011 & 14.701 & & \\
\hline & Total & 2824.387 & & & \\
\hline \multirow[t]{3}{*}{ Managing Strategies } & Between Groups & 93.423 & 31.141 & 4.610 & .004 \\
\hline & Within Groups & 1263.163 & 6.755 & & \\
\hline & Total & 1356.586 & & & \\
\hline \multirow[t]{3}{*}{ Evaluation Strategies } & Between Groups & 76.258 & 25.419 & 4.918 & .003 \\
\hline & Within Groups & 966.485 & 5.168 & & \\
\hline & Total & 1042.743 & & & \\
\hline \multirow[t]{3}{*}{ Whole Scale } & Between Groups & 814.691 & 271.564 & 5.098 & .002 \\
\hline & Within Groups & 9960.482 & 53.265 & & \\
\hline & Total & 10775.173 & & & \\
\hline
\end{tabular}

Table 10 doesn't show significant correlation between pre-service mathematics teachers' metacognitive learning strategies and their perceptions of teacher self-efficacy scores.

Table 10. Correlation between pre-service mathematics teachers' metacognitive learning strategies and their perceptions of self-efficacy scores

\begin{tabular}{lccc}
\hline & $\mathbf{N}$ & $\mathbf{r}$ & $\mathbf{P}$ \\
\hline $\begin{array}{l}\text { Teacher efficacy perceptions } \\
\text { Metacognitive learning strategies }\end{array}$ & 191 & .002 & .975 \\
\hline $\mathrm{p}>.01$ &
\end{tabular}




\section{DISCUSSION and RESULTS}

\subsection{Discussion}

The mean of pre-service mathematics teachers' teacher self-efficacy perceptions scores was found as 157.15. This result is much higher than the average of the scale; when considered that the possible highest score from the scale is 216 , the mean of the scores shows that pre-service mathematics teachers' teacher self-efficacy perceptions are quite high. Many studies have revealed that efficacy perceptions have effects on academic motivation, learning, and achievement. To Riggs and Enochs (1990), self-efficacy belief is used, in the field of education, to explain the individual differences in teachers' performances and it makes great contributions to understanding and improving teacher behaviours. It is reported that teachers' efficacy judgements are related to also many psycho-social factors such as confidence, clarity, job satisfaction, professional motivation, and performance; and, teachers' feeling of efficacy can be an important indicator of many positive teaching practices (Goddard, Hoy \& Woolfolk, 2004). These results give expectations that pre-service primary mathematics teachers will create effective learning environments while they do their job in the future.

According to the research results, while pre-service mathematics teachers' levels of teacher self-efficacy perceptions do not vary across genders, they vary according to grades and the variance is between fourth grade students and the others in favour of the fourth grade. The studies on this issue (Taşkın, Günhan \& Erdal, 2005; Altunçekiç, Üredi \& Üredi, 2006) show that pre-service teachers' efficacy perceptions vary by grades; this variance occurs in a way that as the level of grade increases, level of self-efficacy perceptions increase, too. This finding may have reflected on this study as a result of the courses taken throughout the four-year education, the experiences gained, and the thought of the pre-service teachers they that will start their teaching career.

The mean of the scores the participants took from the Metacognitive Learning Strategies Scale is higher than the overall mean of the scale. To these results, pre-service mathematics teachers' knowledge on information processing process and their awareness and use of the strategies which would help them regulate the learning process by using the functions of controlling, focusing, planning, and evaluating their cognition can be said to be at "good" levels. Such teachers know what they know and what they do not, explain their thinking process, and assess themselves. These skills affect learning settings much more positively.

When the sub-dimensions of the scale were analyzed, according to gender, a significant difference was found in favour of the female participants in "organization strategies" and "managing strategies" sub-dimensions. The items of this sub-dimension included as the strategies of mental preparation show the predetermination and work of the information to be learnt according to the metacognitive schemes in the mind. This strategy which refers to the determination of the titles and key concepts for any learning activity in advance and, for this, an overview of the content to be learnt has an important role in metacognitive learning (Namlu, 2004). But literature findings indicated that there was no significant difference in metacognition levels between males and females. Additionally, a significant difference was found pre-service teachers' grade. (Tüysüz, Karakuyu \& Bilgin, 2008; Özsoy \& Günindi, 2011; Tunca \& Alkın Şahin, 2014).

In the study, a significant difference wasn't found between pre-service mathematics teachers' perceptions of teacher self-efficacy and their metacognitive learning strategies. According to Tunca \& Alkın - Şahin (2014), there are significant relations between the subdimensions of the metacognitive learning strategies and academic self-efficacy. 


\subsection{Results and Suggestions}

Results of this study are given below:

1. Pre-service mathematics teachers' levels of teacher self-efficacy and their knowledge on the structure and processing of their own cognitive system are at "good" levels.

2. It is understood that while pre-service mathematics teachers' perceptions of teacher selfefficacy do not vary by gender, they vary according to the levels of grade and the significant variance is between the 4th grade and others, in favour the 4th grade students.

3. While metacognitive learning strategies at the whole scale level vary by grade and gender, when the sub-dimensions of the scale was analyzed, a significant variance was found in "organization strategies" and "managing strategies" sub-dimensions by gender in favour of female participants.

4. In the study, a significant correlation wasn't found between pre-service mathematics teachers' perceptions of teacher self-efficacy and their metacognitive learning strategies.

The suggestions formulated on the results of the study are as follows:

1.Teaching programmes and environments which will foster pre-service teachers' perceptions of self-efficacy should be developed.

2. Instructors, teachers, and pre-service teachers should be provided with opportunities of training in order to increase the use of metacognitive skills and strategies in cognitive processes.

3. Various studies can be conducted on this topic.

\section{REFERENCES}

Altunçekiç, A., Yaman, S., \& Koray, Ö. (2005). Öğretmen adaylarının öz-yeterlik inanç düzeyleri ve problem çözme becerileri üzerine bir araştırma (Kastamonu ili örneği). Kastamonu Ĕ̆itim Dergisi. 13(1):93-102

Aşkar, P., \& Umay, A. (2001). İlköğretim matematik öğretmenliği öğrencilerinin bilgisayarla ilgili özyeterlik algısı. Hacettepe Üniversitesi Eğitim Fakültesi Dergisi, 21, 1-8

Bandura, A. (1986). Social foundations of though and action: A social cognitive theory. Englewood Cliffs, NJ:PrenticeHall.

Bednarik, K., \& Keinonen, T. (2011). Sixth graders' understanding of their own learning: A case study in environmental education course. International Journal of Environmental and Science Education, 6(1):59-78

Bıkmaz, F. H. (2004). Öz yeterlik inançları. İçinde: Y. Kuzgun ve D. Deryakulu (Ed.). Eğitimde Bireysel Farklllıklar (289-314). Ankara: Nobel Yayın Dağıtım.

Brown, A. (1987). Metacognition, executive control, self-regulation, and other mysterious mechanisms. In F. E. Weinert \& R. H. Kluwe (Eds.), Metacognition, Motivation, and Understanding, (65-116). Hillsdale, NJ: Lawrence Erlbaum Associates

Brownell, M. T., \& Pajares, F. (1999). Teacher efficacy and perceived success in mainstreaming students with learning and behavior problems. Teacher Education and SpecialEducation 22 (3) s. 154-64.

Can, B. T., Günhan, B., \& Erdal, S.(2005). Fen bilgisi öğretmen adaylarının fen derslerinde matematiğin kullanımına yönelik öz yeterlik inançlarının incelenmesi. Dokuz Eylül Üniversitesi Buca Eğitim Fakültesi Dergisi, 18, 38-46.

Davis, J.R., \& Davis, A.B. (2000). Kendi Kendine Öğrenmek, Çev: A. Baykara,Mediacat Yay., Ankara

Eggen, P., \& Don, K. (2001). Educational Psychology, New Jersey, USA

Eshach, H. (2003). Inquiry-events as a tool for changing science teaching efficacy belief of kindergarten and elementary school teachers. Journal of Science Education and Technology, 12(4), 495-501.

Flavell, J. H. (1987). Speculation about the nature and development of metacognition. Metacognition, motivation, and understanding. Weinert \& R. Kluwe (Eds.), Metacognition, motivation, and understanding, 21-29. Hillsdale, NJ: Lawrence Erlbaum 
Gibson, S., \& Dembo, M. (1984). Teacher efficacy: A construct validation. Journal of Educational Psychology, 76 (4), $569-582$.

Goddard, R. G., Hoy, W. K. \& Woolfolk Hoy, A. (2004). Collective efficacy: Theoretical development, empirical evidence, and future directions. Educational Researcher, 33(3) 3-13.

Guskey, T., \& Passaro, P. (1994). Teacher efficacy: A study of construct dimensions, American Educational Research Journal, 31, 627-643.

Hacker, D. J. (1998). Metacognition: Definitions And Empirical Foundations. In: D. J. Hacker, J. Dunlosky, and A. C. Graesser (Eds.). Metacognition In Educational Theory And Practice. Mahwah, NJ: Erlbaum. 1-24.

Hertzog, C. \& Robinson, A. E. (2005). Metacognition and Intelligence. In: O. Wilhelm \& R.W. Engle (Eds), Handbook of Understanding and Measuring Intelligence. London: Sage Publications.

Karasar, N. (2005). Bilimsel Araştırma Yöntemi. Nobel Yayım Dağıtım.

Kurt,T. (2012). Öğretmenlerin öz yeterlik ve kolektif yeterlik algıları. Türk Eğitim Bilimleri Dergisi Bahar 2012, 10(2), 195-227.

Leithwood, K. (2007). What we know abouth educational leadership. J.M. Burger,C. Webber ve P. Knick. (Eds.) Intelligent Leadership, Springer, 41-66.

Namlu, A. G. (2004). Bilişötesi öğrenme stratejileri ölçme aracının geliştirilmesi: geçerlilik ve güvenirlik çalışması. Anadolu Üniversitesi Sosyal Bilimler Dergisi, 4(2).

Nelson, T. O. \& Narens, L. (1996). Why Investigate Metacognition? In J. Metcalfe \& A. P. Shimamura (Eds.). Metacognition. (pp. 1-25). Cambrige, MA: MIT Press.

Özsoy, G. (2007). Illköğretim Beşinci Sinıfta Üstbiliş Stratejileri Öğretiminin Problem Çözme Başarısına Etkisi (Yayımlanmamış Doktora Tezi). Ankara: Gazi Üniversitesi Eğitim Bilimleri Enstitüsü Sınıf Öğretmenliği Ana Bilim Dalı.

Özsoy, G. \& Günindi, Y. (2011). Okulöncesi öğretmen adaylarının üstbilişsel farkındalık düzeyleri. İlköğretim Online Dergisi, 10(2), 430-440.

Riggs, I. M., \& Enochs, L. G. (1990).Toward the development of an elementary teacher's science teaching efficacy belief instrument.Science Education,74.625-637

Sternberg, R. J. (2005). The Triarchic Theory of Successful Intelligence. In: D. P. Flanagan \& P. L. Harrison (Eds.), Contemporary Intellectual Assessment (pp: 103-119). New York: The Guilford Press.

Sternberg, R. J. \& Ben-Zeev, T. (2001). Complex Cognition. New York: Oxford University Press.

Schmitz, G.S. \& Schwarzer, R. (2000). Selbstwirksamkeitserwartung von lehrern: längsschnitt-befunde mit einem neuen instrument. Zeitschrift für Pädagogische Psychologie. 14 (1), 12-25.

Taşkın Can, B., Cantürk Günhan, B. \& Öngel Erdal, S. (2005). Fen bilgisi öğretmen adaylarının fen derslerinde matematiğinkullanımına yönelik öz-yeterlik inançlarının incelenmesi. Pamukkale Üniversitesi Eğitim Fakültesi Dergisi. 17(1), 23.

Tunca, N., \& Alkın-Şahin, S. (2014). Öğretmen Adaylarının Bilişötesi (Üst Biliş) Öğrenme Stratejileri ile Akademik Öz Yeterlik İnançları Arasındaki İlişki. Anadolu Journal of Educational Sciences International, 4 (1), 47-56 Tüysüz, C., Karakuyu Y. \& Bilgin, İ. (2008). Öğretmen adaylarının üst biliş düzeylerinin belirlenmesi. Abant İzzet Baysal Üniversitesi, Sosyal Bilimler Enstitüsü Dergisi, 17(2), 147-158.

Tschannen-Moran, M., \& Hoy, A.W. (2001). Teacher Efficacy: Capturing An Elusive Construct. Teaching and TeacherEducation, 17, 783-805.

Üredi, I., \& Üredi L. (2006). Sınıf öğretmeni adaylarının cinsiyetlerine, bulundukları sınıflara ve başarı düzeylerine göre fen öğretimine ilişkin öz-yeterlik inançlarının karşılaştırılması. Yeditepe Üniversitesi Eğitim Fakültesi Dergisi. 1(2). 23.

Zimmerman, B. J. (1989). A social cognitive view of self-regulated academic learning self-efficacy. Journal of educational psycholgy. 81:329-339.

Zimmerman, B. J., \& Schunk, D. H. (2003). Albert Bandura: The scholar and his contributions to educational psychology. In B. J. Zimmerman \& D. H. Schunk (Eds.), Educational psychology: A century of contributions (pp. 431-458). Mahwah, NJ: Lawrence Erlbaum Press.

\section{Uzun Özet}

$\mathrm{Bu}$ araştırma, İlköğretim Matematik öğretmen adaylarının, öğretmen özyeterlik algısı ile bilişötesi öğrenme stratejileri arasında anlamlı bir ilişkinin olup olmadığı ve adayların öğretmen öz-yeterlik algılar ile bilişötesi öğrenme stratejilerinin, cinsiyet ve sınıf düzeylerine göre farklılık olup olmadığını belirlemek için yapılmıştır. 
$\mathrm{Bu}$ çalışmada tarama modeli kullanılmıştır. Çalışma grubunu, Atatürk Üniversitesi, Kazım Karabekir Eğitim Fakültesi, İlköğretim Matematik Eğitimi Anabilim dalı'nda öğrenim gören toplam 191 öğretmen adayı oluşturmaktadır. Araştırmaya birinci sınıftan 36, ikinci sınıftan 56, üçüncü sınıftan 51 ve dördüncü sınıftan 48 olmak üzere toplam 191 öğretmen adayı çalışmaya katılmıştır. Çalışma, 111 (\%58.1) k1z ve 80 (\%41.9) erkek öğretmen adayından oluşmaktadır. Çalışmada kullanılan Öğretmen Öz-Yeterlik Ölçeği,Tschannen-Moran ve Woolfolk (2001) tarafından geliştirilen öğretmen öz- yeterlik ölçeği, Çapa, Çakıroğlu ve Sarıkaya (2005) tarafından Türkçe’ye uyarlanmıştır. Derse öğrenci katılımını sağlama”, "öğretimsel stratejileri kullanma" ve "sınıf yönetimi” üç alt faktöründen oluşan ölçek 24 madde ve dokuzlu likert tipidir. Ölçekten alınabilecek en düşük puan 24, en yüksek puan 216'dır. Ölçeğin Cronbach alfa kat sayısı tüm ölçek için .93, "öğrencilerin katılımını sağlama” alt boyutuna ilişkin olarak .82, "derste öğretimsel stratejileri kullanma" .86, "sınıf yönetimi” .84 bulunmuştur. Bu çalışmada, Cronbach alfa kat sayısısı "öğrencilerin katılımını sağlama” alt boyutuna ilişkin olarak .846, "derste öğretimsel stratejileri kullanma” .874, "sınıf yönetimi” .881, tüm ölçek için, .951 bulunmuştur. Çalışmada Bilişötesi Öğrenme Stratejileri Ölçeği olarak Namlu (2004) tarafından geliştirilen ölçek, dörtlü likert tipi olup 21 maddeden oluşmaktadır. Ölçeğin Cronbach alfa kat sayıları tüm ölçek için .82, "planlama stratejileri” alt boyutu için .69, “örgütleme stratejileri” için, .74, "denetleme stratejileri” için .67 ve "değerlendirme stratejileri” için .48 bulunmuştur. Bu çalışmada ise ölçeğin Cronbach alfa kat sayısı tüm ölçek için .743, "planlama stratejileri” alt boyutu için .524, "örgütleme stratejileri” için .793, "denetleme stratejileri” için 697 ve "değerlendirme stratejileri” için .532 olarak belirlenmiştir.

Verilerin çözümlenmesinde frekans ve yüzde, aritmetik ortalama, standart sapma, bağımsız gruplar için $t$ testi, tek yönlü varyans analizi, Levene, Pearson Momentler Çarpımı, korelasyon katsayısı teknikleri kullanılmıştır. Çalışma sonucunda öğretmen adaylarının öğretmen öz-yeterlik algısı puanları ortalaması 157.15 olarak bulunmuştur. Bu sonuç, ölçek ortalamasının oldukça üstünde ve ölçekten alınacak en yüksek puanın 216 olduğu düşünülürse, adayların öğretmenliğe yönelik yeterlik algılarının da oldukça yüksek olduğunu göstermektedir. Pek çok araştırma, yeterlik algısının akademik motivasyon, öğrenme ve başarı üzerinde etkili olduğunu göstermiştir. Riggs ve Enochs (1990), öz yeterlik inancı, eğitim alanında, öğretmenlerin performanslarındaki bireysel farklılıkları açıklamak amacıyla kullanılmakta ve öğretmen davranışını anlama ve geliştirmede önemli katkılar sağlamaktadır. öğretmenlerin yeterlik yargılarının güven, açıklık, iş doyumu, mesleki güdülenme ve performans gibi diğer birçok psiko-sosyal ögelerle de ilişkili olduğu ve öğretmenlerin yeterlik hissinin birçok olumlu öğretim uygulamaları için anlamlı bir yordayıcı olabileceği belirtilmektedir (Goddard, Hoy \& Woolfolk, 2004). Bu sonuçlara göre, ilköğretim matematik öğretmen adaylarının mesleklerini icra ederken etkili öğrenme ortamları oluşturacaklarına dair bir beklenti oluşturmaktadır.

Araştırma sonuçlarına göre, öğretmen adaylarının öğretmen öz-yeterlik algısı puanları ortalamaları cinsiyetlerine göre değişmezken, sınıf düzeylerine göre farklılık gösterdiği ve anlamlı farklılığın dördüncü sınıflar arasında, dördüncü sınıfların lehine olduğu anlaşılmaktadır. Bu konuda yapılan araştırmalar (Taşkın Can, Günhan \& Erdal, 2005; Altunçekiç, Üredi \& Üredi, 2006) öğretmen adaylarının yeterlik algılarının sınıf düzeylerine göre farklılaştığını ve bu farklılaşmanın sınıf düzeyi arttıkça yeterlik algısı düzeylerinin de artması şeklinde olduğunu göstermektedir. Bu bulgu adayların dört yıl boyunca aldığı derslerin, edindiği tecrübelerin, mesleklerini icra etmeye başlayacakları düşüncesinin sonucu olarak bu araştırmaya yansımış olabilir.

Öğretmen adaylarının bilişötesi öğrenme stratejileri ölçeğinden aldıkları puanların ortalaması 56.45 olarak bulunmuştur. Öğretmen adaylarının bilişötesi öğrenme stratejileri puan ortalamalarının cinsiyetlerine göre değişip değişmediğini belirlemek için önce Levene testi yapılmış, dağılımın homojen olduğu anlaşılmıştır. Bu sonuca göre ortalamalar arasındaki farkın anlamlı olup olmadığını belirlemek amacıyla bağımsız gruplar için t testi yapılmıştır. Örgütleme, denetleme stratejileri ve tüm ölçek puanları açısından kızların lehine anlamlı bir fark olduğunu göstermektedir. Öğretmen adaylarının bilişötesi öğrenme stratejileri ölçeğinden aldıkları puan ortalaması, ölçeğin ortalamasından yüksektir. Bu sonuçlara göre, öğretmen adaylarının bilgiyi işleme süreci hakkındaki bilgisinin, bilişlerini kontrol etme, merkezde toplama, planlama ve değerlendirme gibi işlevleri kullanarak öğrenme sürecini düzenlemelerine olanak sağlayan stratejileri kullanma ve farkındalıklarının "iyi" düzeyde olduğu söylenebilir. Böyle bir öğretmen adayı neyi bilip bilmediğini bilir, düşünce sürecini ifade edebilir ve kendini değerlendirebilir. Bu beceriler öğrenme ortamlarını daha etkili kılar. Ölçeğin alt boyutları incelendiğinde, cinsiyet değişkenine göre “örgütleme stratejileri” ve "denetleme stratejileri” alt boyutlarında kız adayların lehine anlamlı farklılık bulunmuştur. Öğretmen adaylarının sınıf düzeylerine göre üstbiliş öğrenme stratejilerinin farklılaştığı 
görülmüştür. Zihni hazırlama stratejileri olarak yer alan bu maddeler, öğrenilecek bilginin zihinde yer alan bilişötesi şemalara göre önceden belirlenerek çalışmasını göstermektedir. Herhangi bir öğrenme etkinliği için, önceden konu başlıklarının ve anahtar kavramlarının belirlenmesi, bunun için öğrenilecek içeriğin gözden geçirilmesini ifade eden bu strateji, bilişötesi örenmede önemli bir yere sahiptir (Namlu, 2004). Araştırmada, öğretmen adaylarının öğretmen yeterlik algıları ile bilişötesi öğrenme stratejileri arasındaki ilişki anlamsız bulunmuştur.

$\mathrm{Bu}$ çalışmanın sonuçlarına bakılarak öğretmen adaylarının özyeterlik algılarını geliştirici öğrenme ortamları, eğitim programları oluşturulması ile bilişüstü yetilerin ve stratejilerin bilişsel süreçlerde kullanımını artırmak için öğretim elemanlarına, öğretmen ve öğretmen adaylarına eğitimler verilmesi şeklinde önerilerde bulunulabilir. 